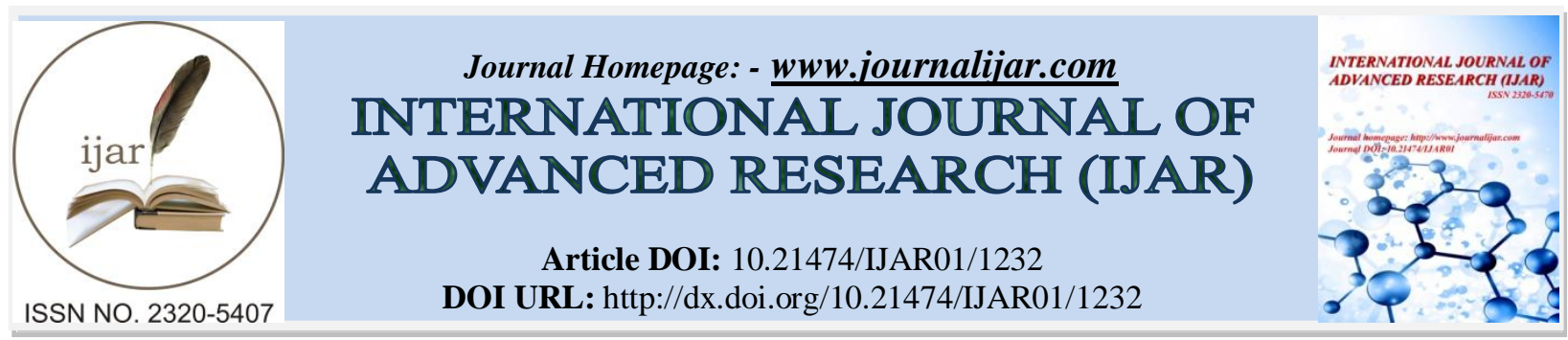

RESEARCH ARTICLE

\title{
POPULATION DYNAMICS OF HELMINTH PARASITE IN FISHES FROM SOLAPUR AND OSMANABAD DIST (M.S) INDIA.
}

\section{Dr.A.M.Fartade ${ }^{1}$ and Dr.R.S. Chati ${ }^{2}$.}

1. Women scientist WOS-A DST Major Research Project Dept.of Zoology .Shri Shivaji Mahavidyalaya, Barshi.

2. Associate Professor, Dept.of Zoology .Shri Shivaji Mahavidyalaya, Barshi.

\section{Manuscript Info}

Manuscript History

Received: 19 June 2016

Final Accepted: 18 July 2016

Published: August 2016

Key words:-

Helminth, fishes, population dynamics, Solapur and Osmanabad dist.

\begin{abstract}
The present study deals with the population dynamics of helminth parasites in fishes from different places of Solapur and Osmanabad dist M.S (India) during August 2015 to July 2016. Helminth parasites were recovered from fishes. This report summaries the percentage of incidences, intensity, density and index of infection. The high prevalence occurs in summer season especially in the month of March and May, while low prevalence occurs in winter season followed by rainy season. The present study indicates the seasonal infection of helminth in fishes.
\end{abstract}

Copy Right, IJAR, 2016,. All rights reserved.

\section{Introduction:-}

Fishes are important animals in ecosystem. They are useful source of human food as well as the source of income. These edible fishes are known to harbor a number of helminth parasite which cause deterioration in their health, hence their market and nutritive value is affected .Parasite can have a wide range of impact on the ecology of their hosts in terms of health (Atme and Owen, 1967) behavior (Milinski 1984, Moore 1984) sexual selection (Howard and Michella, 1990 Watve and Sukumar, 1977) and regulation of the host population (Freeland 1983) parasitic infection tends to decrease the growth rate of the fish. The damage caused by helminths to their hosts is generally related to intensity of infection and depth of parasite penetration with host tissue. Seasonal fluctuation, locality, age, size and sex of the host also determine the parasitic community diversity and burden. Polyanski, 1957 suggested that the diet, lifespan, mode of life, population density and size of the host are the main factors which determine the variety of parasitic species as well as intensity and prevalence of infection. Many authors have carried out studies on the helminth parasites and population dynamics of those occurring in Piscean host and work on different aspects of parasites. The study of population dynamics can be used as the biological basis of method to regulate population of parasite.

\section{Material and Methods:-}

The freshwater fishes are collected from fish market of different places of Solapur and Osmanabad dist. The helminth parasites were collected, preserved, processed to a permanent slide and identified under compound microscope while drawings are made with the aid of camera lucida. The identification was made with the help of "systema Helminthum" Vol II "Helminths of vertebrates" by Yamaguti (1961). 
Population dynamics of helminth parasites were determined by following formula

Infected hosts

- Incidence of Infection $=$

---------------------- x 100

Total hosts examined

Number of parasites collected in a sample

- Intensity of Infection =

Number of infected hosts

Number of parasites collected in a sample

- Density of Infection

Total hosts examined

No. of hosts infected x No. of parasite collected

- Index of Infection = $\quad$ (Total hosts examined) ${ }^{2}$

Population Dynamics of Helminth Parasite in fresh water Fishes from Solapur and Osmanabad District during the year Aug.2015 to July 2016

\begin{tabular}{|c|c|c|c|c|c|c|c|c|c|c|}
\hline Month & $\begin{array}{l}\text { Name of } \\
\text { Parasite }\end{array}$ & $\begin{array}{c}\text { No Of } \\
\text { Host } \\
\text { examine }\end{array}$ & $\begin{array}{c}\text { No of } \\
\text { host } \\
\text { Infecte } \\
\text { d }\end{array}$ & $\begin{array}{c}\text { Total No } \\
\text { of Host } \\
\text { Infected }\end{array}$ & $\begin{array}{l}\text { Total no } \\
\text { parasite } \\
\text { Collected }\end{array}$ & $\begin{array}{c}\text { Inciden } \\
\text { ce }\end{array}$ & Intensity & Density & $\begin{array}{l}\text { Index of } \\
\text { infection }\end{array}$ & $\begin{array}{l}\text { Habitat } \\
\text { /locality }\end{array}$ \\
\hline \multirow{3}{*}{ Aug.15 } & Cestode & \multirow[t]{3}{*}{50} & \multirow[t]{3}{*}{32} & 28 & 27 & 56 & 0.96 & 0.54 & 0.302 & \multirow{3}{*}{ Barshi } \\
\hline & Trematod & & & 00 & 00 & 00 & 00 & 00 & 00 & \\
\hline & Nematode & & & 00 & 00 & 00 & 00 & 00 & 00 & \\
\hline \multirow[t]{3}{*}{ Sept.15 } & Cestode & \multirow[t]{3}{*}{45} & \multirow[t]{3}{*}{17} & 10 & 10 & 22.2 & 01 & 0.22 & 0.049 & \multirow[t]{3}{*}{ Solapur } \\
\hline & Trematode & & & 00 & 00 & 00 & 00 & 00 & 00 & \\
\hline & Nematode & & & 02 & 02 & 4.44 & 01 & 0.44 & 0.0019 & \\
\hline \multirow{3}{*}{ Oct.15 } & Cestode & \multirow[t]{3}{*}{45} & \multirow[t]{3}{*}{07} & 05 & 04 & 11.11 & 0.8 & 0.088 & 0.009 & \multirow[t]{3}{*}{ Osmanabad } \\
\hline & Trematod & & & 00 & 00 & 00 & 00 & 00 & 00 & \\
\hline & Nematode & & & 03 & 03 & 6.66 & 01 & 0.066 & 0.004 & \\
\hline \multirow[t]{3}{*}{ Nov.15 } & Cestode & \multirow[t]{3}{*}{50} & \multirow[t]{3}{*}{25} & 22 & 20 & 44 & 0.90 & 0.4 & 0.176 & \multirow[t]{3}{*}{ Yermala } \\
\hline & Trematod & & & 00 & 00 & 00 & 00 & 00 & 00 & \\
\hline & Nematode & & & 03 & 02 & 06 & 0.66 & 0.04 & 0.002 & \\
\hline \multirow[t]{3}{*}{ Des.15 } & Cestode & \multirow[t]{3}{*}{55} & \multirow[t]{3}{*}{20} & 16 & 05 & 29.0 & 0.312 & 0.09 & 0.0026 & \multirow[t]{3}{*}{ Ujani } \\
\hline & Trematod & & & 00 & 00 & 00 & 00 & 00 & 00 & \\
\hline & Nematode & & & 04 & 02 & 7.27 & 0.5 & 0.036 & 0.0026 & \\
\hline \multirow[t]{3}{*}{ Jan. 16} & Cestode & \multirow[t]{3}{*}{40} & \multirow[t]{3}{*}{24} & 20 & 04 & 50 & 0.2 & 0.1 & 0.05 & \multirow[t]{3}{*}{ Kallamb } \\
\hline & Trematod & & & 00 & 00 & 00 & 00 & 00 & 00 & \\
\hline & Nematode & & & 04 & 02 & 10 & 0.5 & 0.05 & 0.005 & \\
\hline \multirow[t]{3}{*}{ Feb.16 } & Cestode & 37 & 30 & 20 & 15 & 54.05 & 0.75 & 0.40 & 0.219 & Barshi \\
\hline & Trematod & & & 00 & 00 & 00 & 00 & 00 & 00 & \\
\hline & Nematode & & & 10 & 10 & 27.02 & 01 & 0.27 & 0.07 & \\
\hline Mar.16 & Cestode & 55 & 45 & 40 & 20 & 72.72 & 0.5 & 0.36 & 0.26 & Osmanabad \\
\hline & Trematod & & & 00 & 00 & 00 & 00 & 00 & 00 & \\
\hline & Nematode & & & 05 & 08 & 9.09 & 1.6 & 0.14 & 0.013 & \\
\hline Apri.16 & Cestode & 60 & 55 & 50 & 30 & 83.3 & 0.6 & 05 & 0.416 & Solapur \\
\hline & Trematod & & & 00 & 00 & 00 & 00 & 00 & 00 & \\
\hline & Nematode & & & 05 & 09 & 8.33 & 1.8 & 0.15 & 0.0125 & \\
\hline May 16 & Cestode & 65 & 60 & 55 & 25 & 8.46 & 0.45 & 0.38 & 0.325 & Ujani \\
\hline & Trematod & & & 00 & 00 & 00 & 00 & 00 & 00 & \\
\hline & Nematode & & & 05 & 06 & 7.69 & 1.2 & 0.092 & 0.007 & \\
\hline Jun. 16 & Cestode & 70 & 46 & 26 & 10 & 37.1 & 0.38 & 0.14 & 0.053 & Barshi \\
\hline & Trematod & & & 00 & 00 & 00 & 00 & 00 & 00 & \\
\hline & Nematode & & & 20 & 03 & 28.57 & 0.15 & 0.042 & 0.012 & \\
\hline July 16 & Cestode & 50 & 20 & 12 & 05 & 24 & 0.41 & 0.1 & 0.024 & Osmanabad \\
\hline & Trematod & & & 00 & 00 & 00 & 00 & 00 & 00 & \\
\hline & Nematode & & & 08 & 04 & 16 & 05 & 0.08 & 0.0128 & \\
\hline
\end{tabular}



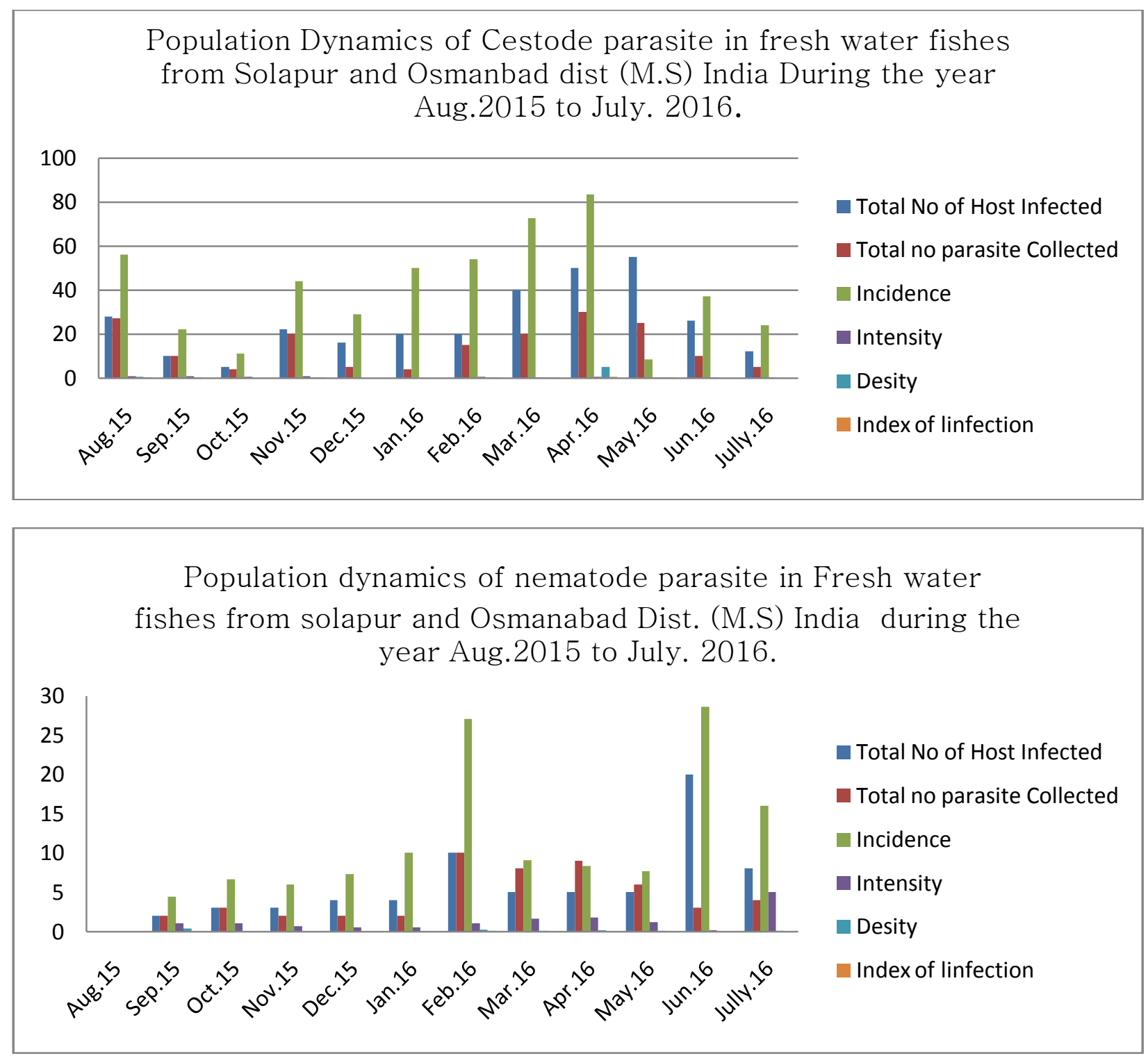

\section{Result and Discussion:-}

The analysis of data shows that the occurrence of helminth parasites variable according to seasons.

The high incidences, intensity, density and index of infection of all the helminth parasites occurred in summer season followed by winter season where as lower infections in mansoon season. The intensity varies greatly with respect to helminth parasites and host species, host size and feeding habitats, season and locality.

Rodhe, 1993 explained the temperature control parasitization. He explained the infections are more in warm seas than old ones. Jadhav (1976, 2005 and 2006) explained the development of parasites should be needed high temperature, low rainfall and sufficient moisture. Hence the high prevalence occurs in summer followed by other season. 


\section{Conclusion:-}

After the analysis of data the present study can be concluded that the high infections of helminth parasite (incidences, intensity, density and index of infection) are occurred in summer season followed by winter where as low in mansoon season. This type of results indicated that environmental factors and feeding habitat are influencing the seasonality of parasitic infection either directly or indirectly.

\section{Bibliography:-}

1. Anderson R.M. (1976): Seasonal variation in the population dynamics of Caryophyllaceouslattices. Parasitol (72) 281-395.

2. Baba Jadhav et.al. (2008): Caryophyllidean review from catfishes of Maharashtra (India) Flora and Fauna 14(1) 03-22.

3. Baylis H.A (1928): Some parasitic worms from Lake Tanganyika Ann.Mag.Hist.ser 10

4. Dhole Jaywant, Sushil jawale et al (2009): Population dynamics of cestode parasites in Mastacembelus armatus (LCEPEDE 1800) from Osmanabad District (M.S) India Ecotech 1(2) 156-159.

5. Dobson V.A. (1985): The population dynamics of competition between parasites .Parasitol 1(2) 317-347.

6. Dogiel V.A. (1985): Parasitology of fishes Leningrand University press. Olivear and Boyed Edinburgh and London 1-348.

7. Esch G.W (1977): Regulation of parasitic population Academic press .INC, New York 253.552-562.

8. Hiware C.J et. al (2007): Population dynamics of the proteocephalids cestode parasitizing freshwater catfish mystus cavasius . Flora and Fauna 13(2) 384-388.

9. Hiware C.J (1999) :Population dynamics of the Caryophyllidean cestode parasitizing freshwater air breathing predatory fish Clarias batrachus Linnaeus Riv.Di.Parasitol.19(1)

10. Jadhav B.V. et.al (2006): Population dynamics of the helminth parasite in freshwater fishes from Marathwada region (M.S) India .Flora and Fauna 12(2) 143-148.

11. Kennedy C.R. (1976): Ecologiacal aspect of parasitology North Holand publishing compny. Amsterdam 10x Ford.

12. Pennyuick K.L (1973): seasonal variation in the parasite population of three spined stickle backs Gasterostes aculeatus L.parasitol.63;373-388.

13. Satpute L.R and Agarwal S.M (1974): Seasonal infection of Clarias batrachus (Bloch) by lytocestus indicus moghe and parasitic effects on its hematology and histopathology .ind.j.exp.Biol.12(6) 584-586.

14. Sunita Borde Sushil Jawale (2012): Population dynamics of caryophyllidean tapeworms in clarias batrachus from Aurangabad Districts (M.S) India.Trends in parasitology Research Vol I ,1 2319-314X(print); 2319-3158.

15. Thomas J.D (1964): Studies on population of helminth parasites in trout(Salmontrutta 1) Anim. Eco 33: 83-85

16. Williams D.D. (1978 a) seasonal incidences of Isoglariadacris wisconsinensis (Cestoda:Caryophyllaeidae) in its fish host. Lowstate Res 53(4) : 305-310.

17. Yamaguti S (1934) : Studies on Helminth fauna of Japan part IV, Cestodes of fishes. Jap.J. Zool.(6): 1-12 